\title{
DNA methylation in infants with low and high body fatness
}

Pontus Henriksson ${ }^{1 *} \mathbb{D}$, Antonio Lentini ${ }^{2}$, Signe Altmäe ${ }^{3,4}$, David Brodin $^{5}$, Patrick Müller $^{5}$, Elisabet Forsum ${ }^{6}$, Colm E. Nestor ${ }^{2+}$ and Marie Löf ${ }^{1,5+}$

\begin{abstract}
Background: Birth weight is determined by the interplay between infant genetics and the intrauterine environment and is associated with several health outcomes in later life. Many studies have reported an association between birth weight and DNA methylation in infants and suggest that altered epigenetics may underlie birthweight-associated health outcomes. However, birth weight is a relatively nonspecific measure of fetal growth and consists of fat mass and fat-free mass which may have different effects on health outcomes which motivates studies of infant body composition and DNA methylation. Here, we combined genome-wide DNA methylation profiling of buccal cells from 47 full-term one-week old infants with accurate measurements of infant fat mass and fat-free mass using air-displacement plethysmography.

Results: No significant association was found between DNA methylation in infant buccal cells and infant body composition. Moreover, no association between infant DNA methylation and parental body composition or indicators of maternal glucose metabolism were found.

Conclusions: Despite accurate measures of body composition, we did not identify any associations between infant body fatness and DNA methylation. These results are consistent with recent studies that generally have identified only weak associations between DNA methylation and birthweight. Although our results should be confirmed by additional larger studies, our findings may suggest that differences in DNA methylation between individuals with low and high body fatness may be established later in childhood.
\end{abstract}

\section{Background}

Epigenetic variations, such as DNA methylation, have been associated with a growing number of chronic diseases and conditions, including obesity [1-5]. Interestingly, the intrauterine environment may alter DNA methylation patterns in the developing embryo and associations between DNA methylation in neonatal blood and maternal body mass index (BMI), gestational weight gain and smoking have been reported [6, 7]. These associations are supported by animal models in which diet-

\footnotetext{
* Correspondence: pontus.henriksson@liu.se

${ }^{\dagger}$ Colm E. Nestor and Marie Löf are joint senior authors

${ }^{1}$ Department of Health, Medicine and Caring Sciences, Linköping University, 58183 Linköping, Sweden

Full list of author information is available at the end of the article
}

induced epigenetic changes and their associated phenotypes have been transmitted across multiple generations [8-10] and epidemiological studies have hypothesized that extremes in diet may result in altered disease risk in subsequent generations, possibly via an epigenetic mechanism [11, 12]. Moreover, recent studies have identified an association between neonatal blood DNA methylation and birth weight $[13,14]$. As birth weight is predictive of several health outcomes later in life $[15,16]$, DNA methylation has been proposed as a potential molecular mechanism underlying these associations.

How DNA methylation changes may causally contribute to fatness phenotypes in humans remains unresolved, but a growing body of evidence supports the potential of minor epigenetic changes in early development to cause

(c) The Author(s). 2020 Open Access This article is licensed under a Creative Commons Attribution 4.0 International License, which permits use, sharing, adaptation, distribution and reproduction in any medium or format, as long as you give appropriate credit to the original author(s) and the source, provide a link to the Creative Commons licence, and indicate if changes were made. The images or other third party material in this article are included in the article's Creative Commons licence, unless indicated otherwise in a credit line to the material. If material is not included in the article's Creative Commons licence and your intended use is not permitted by statutory regulation or exceeds the permitted use, you will need to obtain permission directly from the copyright holder. To view a copy of this licence, visit http://creativecommons.org/licenses/by/4.0/ The Creative Commons Public Domain Dedication waiver (http://creativecommons.org/publicdomain/zero/1.0/) applies to the data made available in this article, unless otherwise stated in a credit line to the data. 
large changes in body composition [17, 18]. Indeed, we previously showed that subtle epigenetic variation in early mouse development can result in profound changes in littermate body composition [18]. Building on our work in mouse, Pospisilik and colleagues [17] have demonstrated that similar transcriptional variance during early development could result in a stable bi-modal phenotype; obese or not-obese. Importantly, identification of an imprinted gene network as causal in the bi-modal phenotype and it's recapitulation in a cohort of lean and obese children [17], highlights the potential of epigenetic dysregulation in generation of fat related phenotypes in human [19]. Genomic imprinting as a source of epigenetic-driven alterations in body composition are particularly attractive as DNA methylation is essential for establishing and maintaining genomic imprints and genetic loss of imprinting is typically associated with over-growth and metabolic phenotypes [20].

Birth weight is however a nonspecific measure of fetal growth and consists of fat mass and fat-free mass. This is of importance since fat mass and fat-free mass may have different effects on health outcomes in adulthood [21] as well as during childhood and infancy [22, 23]. Noteworthy, the commonly used surrogate measure for body fatness, BMI, as well as birth weight are poor markers of body fatness in infants [24, 25]. The lack of accurate measurements of infant body composition may underlie the typically weak and often divergent associations between DNA methylation and infant birth weight $[13,14]$. Therefore, we hypothesized that an accurate measure of body fatness would provide stronger association with infant DNA methylation. Hence, we measured body fatness accurately using air-displacement plethysmography (ADP) in a cohort of healthy full-term infants [26] and generated base-resolution genome-wide maps of buccal cell DNA methylation from the same infants. The advantage of ADP is that body composition (both fat and fat-free body mass) can be measured accurately in a quick and non-invasive manner [27, 28]. To help identify factors that could influence in utero development and associated DNA methylation patterns we also used ADP to measure body composition in the fathers and mothers in gestational week 32, as well as key measures of glucose metabolism and insulin resistance during pregnancy.

Using our novel approach, we found no association between any measures of body fatness in infants and neonatal buccal cell DNA methylation. Moreover, no association between DNA methylation in infant buccal cells and parental body composition or maternal insulin resistance was identified. Thus, our findings suggest that differences in DNA methylation between individuals with low and high body fatness may be established later in childhood.

\section{Results}

The DNA methylation profile of buccal cells fails to separate newborns with high or low body fatness

In order to study the early programming effects of body fatness in humans we characterized the DNA methylation patterns of buccal cell isolated from those infants identified as having the lowest $(N=23)$ and highest $(N=24)$ body fatness in the PArents and THeir OffSpring (PATHOS) study (Fig. 1a). Body fatness was defined as fat mass $(\mathrm{kg})$ divided by body weight $(\mathrm{kg})$. Characteristics of study participants are summarized in Table 1. No differences in gestational age (independent t-test; $P=0.22$ ) or in the fat-free mass index (i.e. fat-free mass normalized for height) (independent t-test; $P=0.12$ ) between infants with low and high body fatness were observed. Furthermore, no statistically significant differences (independent $\mathrm{t}$-test) in parental age, parental BMI, parental body composition as well as maternal glycemia were observed between infants with low and high body fatness.

Genome-wide DNA methylation was determined using llumina ${ }^{\circ} 450 \mathrm{~K}$ DNA methylation microarrays. As expected, principal components analysis (PCA) did not cluster the data according to infant body fatness group (Fig. 1b). Unsupervised hierarchical clustering also showed no association with other potential confounders of sex or microarray-based batch effects (Fig. 1c). Thus, no global differences in DNA methylation patterns were observed between infants with high or low body fatness. We next attempted to associate body fatness with DNA methylation levels at individual $\mathrm{CpG}$ sites. Despite removal of nonvariable sites to increase sensitivity (Supplementary Figure $1 \mathrm{~B}$, see methods), no significant associations between DNA methylation levels and infant body fatness (low versus high body fatness) were detected (F-test, $F D R<0.05$ ) (Fig. 1d). Thus, differences in infant body fatness were not associated with global or locus-specific changes in DNA methylation in buccal cells.

Given the small sample size of the current study, the absence of association observed may reflect a lack of power to detect smaller yet biologically meaningful associations. Thus, we next sought to determine if those probes showing greatest rank association with infant fatness were enriched for loci identified in previous large-scale EWAS of BMI. No overlap was found between the top 1000 probes reported here and the 156 probes showing statistically significant association between BMI and methylation in the largest EWAS of BMI to date [29]. Furthermore, we found no significant overlap $(N=3, P>0.05$, Fishers exact test) between the top 1000 probes identified here and 
A

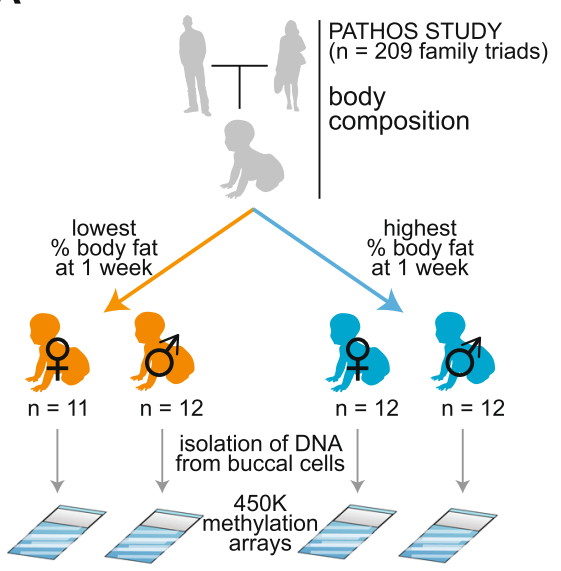

B

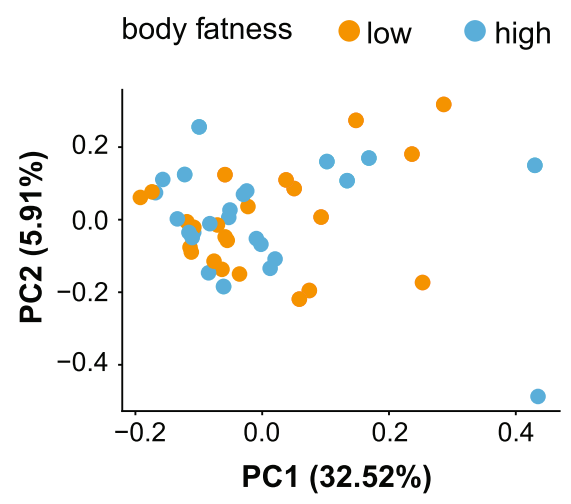

C

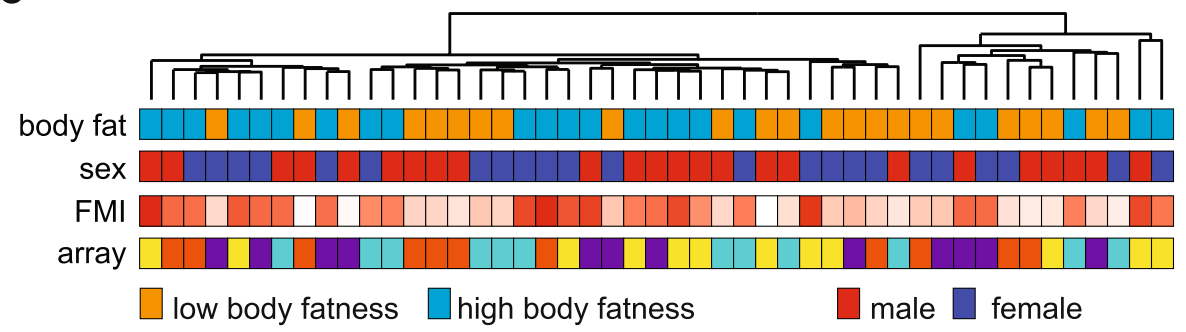

D

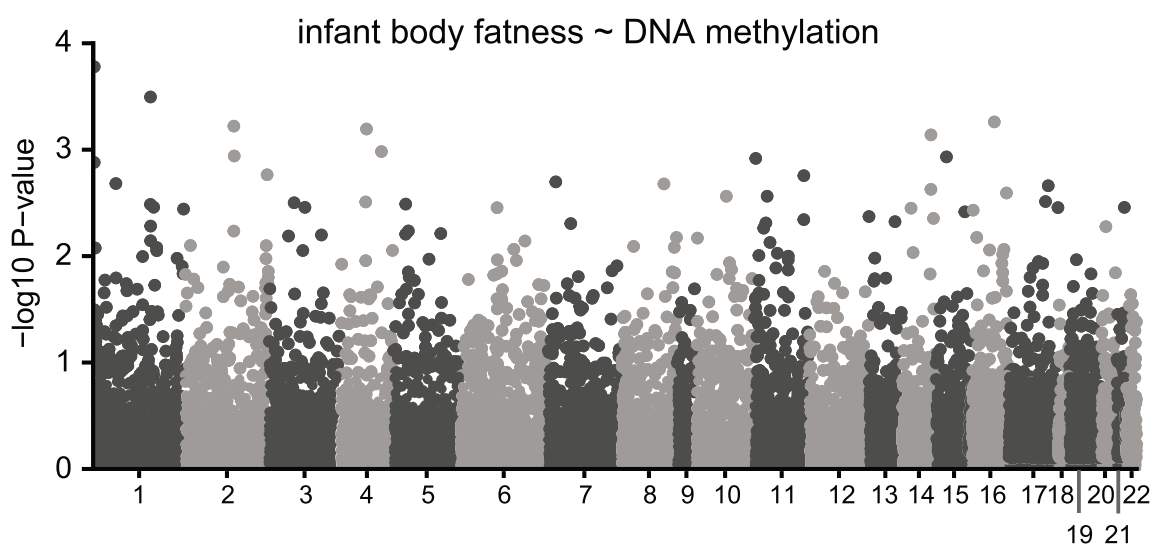

chromosome

Fig. 1 The DNA methylation profile of buccal cells fails to separate newborns with high or low body fatness. (a) Outline of experimental design: Buccal cells were isolated from those newborns with the highest $(N=23)$ and lowest $(N=24)$ body fatness enrolled the PATHOS (PArents and THeir OffSpring) study. Genomic DNA was isolated from buccal cells, bisulfite-treated and applied to Illumina Infinium 450 k DNA methylation arrays. (b) Principle components analysis failed to cluster methylation data by fatness (c) Unsupervised hierarchical clustering of the same data also failed to separate subjects by body fatness, sex, fat mass index (FMI) or array. (d) Manhattan plot showing of association of genome-wide DNA methylation levels with infant body fatness. No probes were significantly associated with body fatness after adjusting for multiple correction $\left(F R_{\text {ADJUSTED }}=0.05\right)$

those identified in the ALSPAC study of maternal pre-pregnancy BMI and offspring blood DNA methylation $(N=1649)[6]$. Interestingly, there was also no overlap between the significant probes identified in the ALSPAC $(N=1649)$ study and the EWAS of BMI and adverse outcomes of adiposity $(N=156)$. 
Table 1 Characteristic of the infants in the study

\begin{tabular}{|c|c|c|c|}
\hline & $\begin{array}{l}\text { Infants with low body } \\
\text { fatness }(n=23)\end{array}$ & $\begin{array}{l}\text { Infants with high body } \\
\text { fatness }(n=24)\end{array}$ & \\
\hline & Value & Value & $P$-value ${ }^{\text {a }}$ \\
\hline \multicolumn{4}{|l|}{ Infant characteristics } \\
\hline Birth weight ${ }^{b}(g)$ & $3320 \pm 315$ & $4045 \pm 416$ & $<0.001$ \\
\hline Gestational age at birth (week) & $40.2 \pm 1.1$ & $40.6 \pm 1.0$ & 0.22 \\
\hline Female sex (n) & 11 & 12 & \\
\hline Male sex (n) & 12 & 12 & \\
\hline Age at measurement (week) & $1.1 \pm 0.2$ & $1.0 \pm 0.3$ & 0.51 \\
\hline Weight at 1 wk. (g) & $3271 \pm 298$ & $4024 \pm 361$ & $<0.001$ \\
\hline Length at $1 \mathrm{wk} .(\mathrm{cm})$ & $51.1 \pm 1.2$ & $52.4 \pm 1.3$ & 0.001 \\
\hline$\%$ fat mass at $1 \mathrm{wk}$. & $6.5 \pm 2.7$ & $17.6 \pm 1.6$ & $<0.001$ \\
\hline BMl at $1 \mathrm{wk} .\left(\mathrm{kg} / \mathrm{m}^{2}\right)$ & $12.5 \pm 0.8$ & $14.6 \pm 1.1$ & $<0.001$ \\
\hline Fat mass index at $1 \mathrm{wk} .\left(\mathrm{kg} / \mathrm{m}^{2}\right)$ & $0.82 \pm 0.36$ & $2.57 \pm 0.36$ & $<0.001$ \\
\hline Fat-free mass index at $1 \mathrm{wk} .\left(\mathrm{kg} / \mathrm{m}^{2}\right)$ & $11.7 \pm 0.7$ & $12.1 \pm 0.8$ & 0.12 \\
\hline \multicolumn{4}{|l|}{ Maternal characteristics } \\
\hline Age (year) & $30.6 \pm 3.3$ & $30.6 \pm 4.1$ & 0.98 \\
\hline Pre-pregnancy BMI ${ }^{2}\left(\mathrm{~kg} / \mathrm{m}^{2}\right)$ & $22.6 \pm 3.3$ & $22.6 \pm 3.1$ & 0.96 \\
\hline $\mathrm{BMI}^{\mathrm{c}}\left(\mathrm{kg} / \mathrm{m}^{2}\right)$ & $26.0 \pm 3.6$ & $26.7 \pm 3.3$ & 0.47 \\
\hline$\%$ fat mass ${ }^{c}$ & $33.8 \pm 5.2$ & $33.9 \pm 5.2$ & 0.98 \\
\hline Fat mass index $\left(\mathrm{kg} / \mathrm{m}^{2}\right)$ & $8.9 \pm 2.5$ & $9.2 \pm 2.5$ & 0.72 \\
\hline Fat-free mass index $\left(\mathrm{kg} / \mathrm{m}^{2}\right)$ & $17.1 \pm 1.6$ & $17.5 \pm 1.3$ & 0.26 \\
\hline HOMA-IR & $1.7 \pm 0.7$ & $2.1 \pm 0.9$ & 0.74 \\
\hline Glycaemia $^{c}(\mathrm{mmol} / \mathrm{L})$ & $4.7 \pm 0.3$ & $4.8 \pm 0.2$ & 0.12 \\
\hline \multicolumn{4}{|l|}{ Paternal characteristics } \\
\hline Age (year) & $33.9 \pm 5.0$ & $32.8 \pm 4.4$ & 0.43 \\
\hline $\mathrm{BMl}^{\mathrm{C}}\left(\mathrm{kg} / \mathrm{m}^{2}\right)$ & $25.5 \pm 4.3$ & $25.3 \pm 4.7$ & 0.47 \\
\hline$\%$ fat mass ${ }^{c}$ & $23.7 \pm 10.0$ & $23.9 \pm 8.8$ & 0.98 \\
\hline Fat mass index $\left(\mathrm{kg} / \mathrm{m}^{2}\right)$ & $6.4 \pm 3.8$ & $6.3 \pm 3.6$ & 0.94 \\
\hline Fat-free mass index $\left(\mathrm{kg} / \mathrm{m}^{2}\right)$ & $19.1 \pm 1.6$ & $18.9 \pm 1.8$ & 0.70 \\
\hline
\end{tabular}

BMI Body mass index, HOMA-IR homeostasis model assessment-insulin resistance

Values are mean \pm SD or $n$

${ }^{\text {a }}$ Refers to the $P$ value of an independent t-test

${ }^{b}$ Self-reported by the mother

c Measured when mother was in gestational week 32

\section{Characterizing the association between parental phenotype and infant DNA methylation}

The in utero environment has been associated with both infant size (e.g [26, 30, 31]) and methylation levels [6]. Thus, we investigated if the DNA methylation patterns observed in infant buccal cells reflected maternal characteristics during gestation. Again, no loci were significantly associated with maternal BMI, fat mass index or fat-free mass index (Linear regression, FDR $<0.05$ ) (Fig. 2a-c). Similarly, no association between maternal insulin resistance and beta-cell function as measured using HOMA-IR) in gestation al week 32 was observed (Supplementary Figure 2A). Finally, there was essentially no evidence for an association of paternal body composition or other infant body composition variables (than body fatness) with infant DNA methylation (Supplementary Figure 2C).

\section{Discussion}

Obesity is a global public health issue and is strongly related to impaired health and quality of life [32]. Birth weight has been related to DNA methylation in infancy $[13,14]$ as well as health outcomes in later life, such as obesity and mortality $[15,16]$. Previous studies have generally reported weak associations between birth weight and DNA methylation in infant blood despite very large sample sizes $[13,14]$. However, infants with similar birth weight can have very different levels of body fatness 

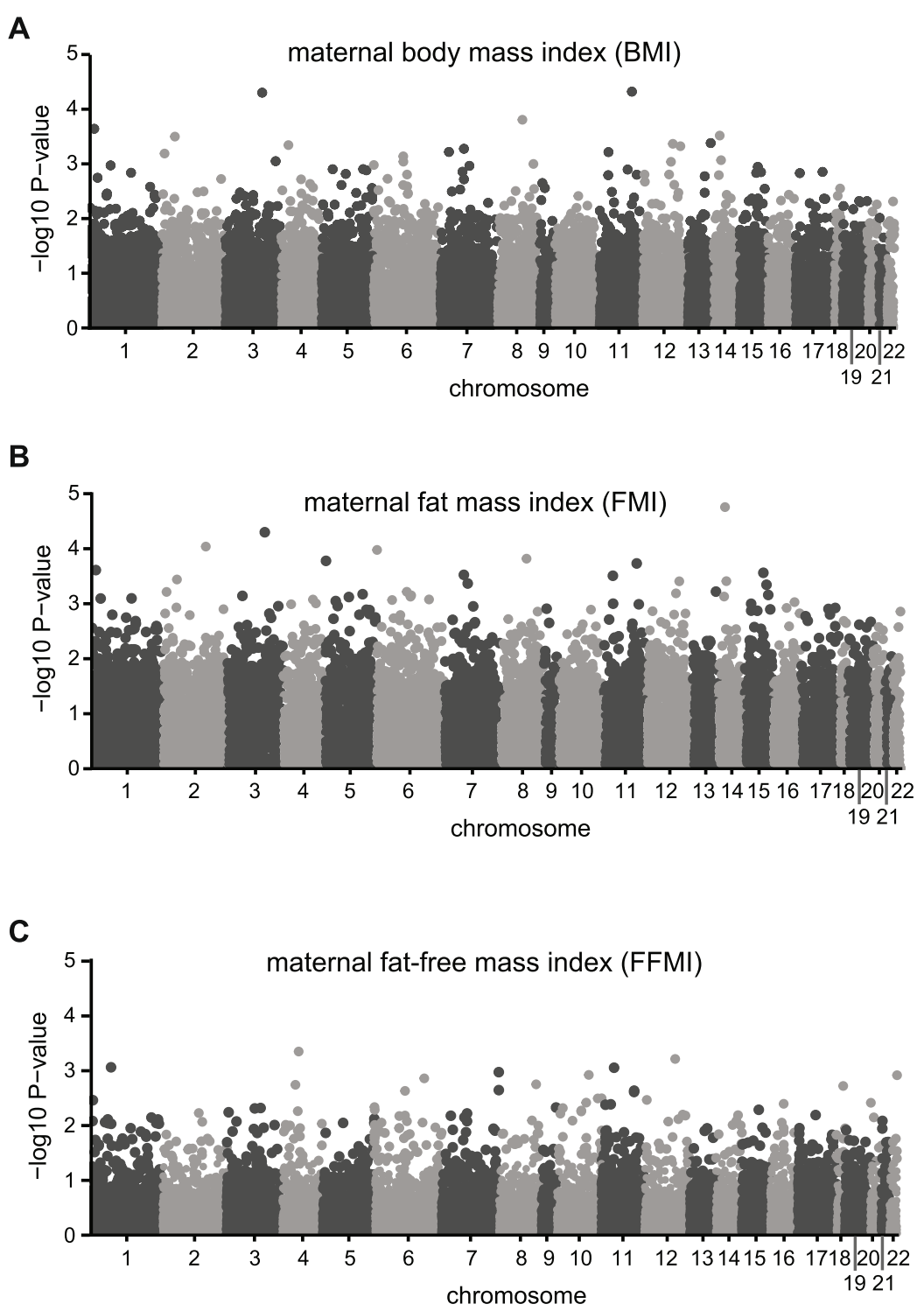

Fig. 2 No association between maternal phenotype and infant DNA methylation. (a-c) Manhattan plots showing lack of association $\left(F_{\text {ADJUSTED }}=0.05\right)$ between DNA methylation levels and $(\mathbf{a})$ maternal body mass index, (b) maternal fat mass index and $(\mathbf{c})$ maternal fat-free mass index

[33]. Consequently, we sought to investigate if accurate assessment of body composition could reveal any biological meaningful associations between DNA methylation and body fatness in newborns.

This study is the first to directly test whether DNA methylation differs between infants with low or high body fatness. Using this novel approach, we did not identify any differences in DNA methylation across the body fatness categories. Moreover, no association between parental body composition and maternal glucose homeostasis with DNA methylation in infants was observed. Whereas our results are somewhat in contrast to previous studies of birth weight and DNA methylation in blood [13, 14], we note that the previously reported differences in DNA methylation associated with birth weight identified are few and typically too small to have a functional impact on gene expression with little overlap between independent studies [14]. Our results may also be compared with previous studies that have examined genetic variation in relation to adiposity in childhood. Although studies have linked a few loci to birth weight these loci have generally not been associated with adiposity later in life [34]. Furthermore, there has been little evidence linking gene variants to infant body fatness [26, 35]. Studies in older children have reported associations between adiposity and several gene variants including single-nucleotide polymorphism in the FTOgene $[36,37]$ which is the strongest obesity associated 
gene variant in adulthood [34]. Interestingly, the influence of FTO gene variant on adiposity appears to be small in infancy but strengthens considerably during childhood [38]. These results may be reconciled with our results and previous studies which have shown association between adiposity and DNA methylation in older children which include studies of both blood [39, 40] and saliva samples $[41,42]$.

The major strength of the current study is the wellcategorized cohort of parents and infants which also included accurate measure of body composition [27, 43]. Nevertheless, the study also has several limitations. First, an important limitation of the study is its relatively small sample size $(N=47)$, which compromises the power of the study to detect small, but significant associations between DNA methylation and body fatness. Calculating significant difference in EWAS using DNA methylation arrays is complex and no standard significance thresholds exist. Using a recently described simulation-based approach to estimating the 5\% family-wise error rate for methylation array studies, the current study has $80 \%$ predicted power to detect $>5 \%$ methylation differences at $25 \%$ of $\mathrm{CpG}$ sites on the array and $>2 \%$ methylation differences at just $4 \%$ of sites [44]. Consequently, the current study is limited to detection of relatively large differences in DNA methylation between infant with low and high body fatness. Second, although the study included infants with a wide range in body fatness, they all came from a well-nourished population which motivates further studies in populations with a more heterogeneous nutritional status. Third, the use of buccal epithelial cell (BEC) DNA obtained from buccal swabs, instead of other relevant tissues such as adipose or liver tissue, is a potential limitation of the study. Our use of BECs as a surrogate tissue was motivated by several factors including the relativity easy and non-invasive collection of DNA [45] which was also supported by the fact that we were able to collect DNA from all 209 infants in the PATHOS study [26]. Moreover, a growing body of evidence supports the use of BECs over blood in EWAS [46-48]. DNA methylation patterns in blood are profoundly different from those in most other somatic tissues questioning their choice as a surrogate for nonblood related phenotypes [46, 48]. BECs exhibit higher, and more consistent inter-individual DNA methylation variation, increasing the effective power of BEC EWAS over blood EWAS. In addition, biological and technical replicates of BECs show more stability between samples than blood, reducing noise [49]. Finally, differentially methylated regions (DMRs) in BECs more often overlap known disease-associated SNPs than blood DMRs [47]. Although buccal swabs were carefully performed, BEC preparations can be contaminated with non-epithelial cells, such as lymphocytes, which may lower the predictive power of the study, but would not be expected to vary between groups.

\section{Conclusion}

In conclusion, this study reports no difference in genome-wide DNA methylation between 1-week-old infants with low and high body fatness. Although our findings require confirmation by future larger studies, our results indicate that potential differences in DNA methylation between lean and obese individuals may develop later in childhood.

\section{Methods \\ Study participants}

This pilot study utilized data from a previous study called the PATHOS (PArents and THeir OffSpring) study, which investigated associations of parental and infant body composition early in life $[26,50]$. In order to maximize the statistical power and since we hypothesized that the largest differences in DNA methylation would be between extremes in infant body fatness, we selected the 24 infants (12 girls and 12 boys) with the lowest body fatness (range: $0.9-9.8 \%$ fat mass) and the 24 infants (12 girls and 12 boys) with the highest body fatness (range: $15.1-21.1 \%$ fat mass) at 1 week of age for this study.

The study was approved by the Regional Ethics Committee (reference numbers: M187-07 and 2012/440-32), Linköping and informed consent, witnessed and formally documented, was obtained from the parents.

\section{Body composition of infants and their parents}

At 1 week of age, infant length and weight were assessed using standardized procedures and subsequently, the body composition of the infants was measuring using ADP and the Fomon model (Pea Pod, COSMED USA, Inc., Concord, CA, USA), see our previous study for more detailed information [50]. The height, weight and body composition of both mothers and fathers were measured after an overnight fast when the mother was in gestational week 32 . Briefly, body composition was assess by ADP (Bod Pod, COSMED USA, Inc., Concord, CA, USA) as previously described [30, 50]. Furthermore, a fasting blood sample was collected from the mother to determine plasma glucose and serum insulin. None of the mothers were diagnosed with gestational diabetes. Maternal HOMA-IR (homeostasis model assessmentinsulin resistance) was calculated according to Matthews et al. [51]. Maternal pre-pregnancy weight was selfreported at the measurement in gestational week 32 . BMI [weight $(\mathrm{kg}) /$ height $^{2}(\mathrm{~m})$ ], fat mass index [FMI; fat mass $\left.(\mathrm{kg}) / \mathrm{height}^{2}(\mathrm{~m})\right]$, and fat-free mass index [FFMI; fat-free mass $(\mathrm{kg}) /$ height $\left.^{2}(\mathrm{~m})\right]$ were calculated. 
DNA extraction and DNA methylation analysis

A buccal swab was performed on the infants and subsequently DNA was extracted using QuickExtract DNA Extraction Solution 1.0 (Epicentre Biotechnologies, Madison, WI, USA). DNA quality was assessed by using Agilent Genomic DNA ScreenTape System and DNA concentration was measured using Qubit fluorometer. DNA was stored in $-20{ }^{\circ} \mathrm{C}$ for further analysis. $500 \mathrm{ng}$ of genomic DNA was bisulfate converted with EZ-96 DNA Methylation kit (Zymo Research, Irvine, CA, USA) and genome wide DNA methylation analysis was performed using the Infinium Human Methylation $450 \mathrm{~K}$ BeadChip (Illumina, San Diego, CA, USA) according to the manufacturer's instructions.

\section{Methylation data analysis}

Illumina $450 \mathrm{~K}$ DNA methylation data was preprocessed using functional normalization [52] as implemented in minfi [53]. One sample did not pass quality control and was excluded from further analyses (Supplementary Figure 1A). Next, problematic probes were excluded based on general purpose masking [54] and only autosomes were kept. Differentially methylated region (DMR) analysis using the minfi bumphunter function (cutoff $=0.2$ and bootstraps $(B)=1000$ ) [53] yielded only two DMRs consisting of single probes with FWERs > 0.05 (data not shown), therefore we focused on single CpGs instead. Differentially methylated probes (DMPs) were identified using the minfi dmpFinder function using default settings [53]. Briefly, continuous variables (BMI, FMI, FFMI and log HOMA-IR) were tested with linear regression and categorical variables (infant body fatness group) were tested with F-tests. To increase statistical power in identifying DMPs after multiple-testing correction, invariant probes related to cell type were filtered as previously described [55] but with a more stringent requirement of at least $20 \%$ variability between the 10th and 90th percentile, this represented approximately the top 5th percentile of variable CpGs. The remaining 20,027 filtered DMP $P$-values were false discovery rate (FDR)-corrected to account for multiple testing.

\section{Supplementary Information}

Supplementary information accompanies this paper at https://doi.org/10. 1186/s12864-020-07169-7.

Additional file 1: Supplementary Figure 1. DNA methylation quality control and pre-processing. (A) Density plot showing expected bi-modal distribution of DNA methylation values in all samples except one (dashed line) (top) and fraction of failed probe positions per sample based on detection $P$-values $(P>0.01)$ (bottom). (B) Plot showing the variability cutoff below which probes were excluded from linear regression studies of association (see methods). Supplementary Figure 2. No association between parental phenotype and infant DNA methylation levels. (A) Manhattan plot showing lack of association (FDR $\mathrm{ADJUSTED}=0.05)$ between infant DNA methylation levels and maternal homeostatic model assessment insulin resistance (HOMA-IR) score. (B) Manhattan plots showing lack of association (FDR ADJUSTED $=0.05)$ between DNA methylation levels and infant body mass index, infant fat mass index and infant fatfree mass index. (C) Manhattan plots showing lack of association (FDR ADJUSTED $=0.05$ ) between DNA methylation levels and paternal body mass index, paternal fat mass index and paternal fat-free mass index.

\section{Abbreviations}

ADP: Air-displacement plethysmography; BMI: Body mass index; DMP: Differentially methylated probes; FDR: False discovery rate; FFMI: Fatfree mass index; FMI: Fat mass index; HOMA-IR: Homeostasis model assessment-insulin resistance; PATHOS study: PArents and THeir OffSpring study; PCA: Principal components analysis

\section{Acknowledgements}

The authors gratefully thank the parents and children that participated in the PATHOS study.

Authors' contributions

$\mathrm{PH}, \mathrm{CEN}$, EF and ML conceived, designed and lead the study. AL performed all bioinformatics. SA, DB and PM contributed to data analysis. CEN and PH performed the primary manuscript writing. $\mathrm{AL}$ and $\mathrm{ML}$ contributed to manuscript writing. All authors reviewed the manuscript and approved the final version of the manuscript.

\section{Funding}

The study was funded by Formas (data collection) and a grant from Bo and Vera Ax:son Johnsons Foundation (data analysis) (both ML). CEN was supported by grants from the Swedish Research Council (2015-03495) and the Swedish Cancer Society (CAN 2017/625). SA was supported by grants from the Spanish Ministry of Economy, Industry and Competitiveness (MINE CO) and European Regional Development Fund (FEDER) grants: RYC-201621199 and ENDORE SAF2017-87526. The funding body had no role in the design of the study, data collection, analysis and interpretation of data, writing of the manuscript and the decision to publish. Open Access funding provided by Linköping University Library.

\section{Availability of data and materials}

The raw data has been deposited in the public functional genomics data repository, ArrayExpress (https://www.ebi.ac.uk/arrayexpress/), under the accession number E-MTAB-9596. The raw data will be made publicly available upon publication of the article.

Ethics approval and consent to participate

The study was approved by the Regional Ethics Committee, Linköping, Sweden (reference numbers: M187-07 and 2012/440-32).

\section{Consent for publication}

Not applicable.

\section{Competing interests}

Authors declare no competing interests.

\section{Author details}

${ }^{1}$ Department of Health, Medicine and Caring Sciences, Linköping University, 58183 Linköping, Sweden. ${ }^{2}$ Crown Princess Victoria Children's Hospital, and Department of Biomedical and Clinical Sciences (BKV), Linköping University, Linköping, Sweden. ${ }^{3}$ Department of Biochemistry and Molecular Biology, Faculty of Sciences, University of Granada, Granada, Spain. ${ }^{4}$ Instituto de Investigación Biosanitaria ibs.GRANADA, Granada, Spain. ${ }^{5}$ Department of Biosciences and Nutrition, Karolinska Institutet, Huddinge, Sweden.

${ }^{6}$ Department of Biomedical and Clinical Sciences (BKV), Linköping University, Linköping, Sweden. 
Received: 13 April 2020 Accepted: 20 October 2020

Published online: 09 November 2020

\section{References}

1. Ding X, Zheng D, Fan C, Liu Z, Dong H, Lu Y, Qi K. Genome-wide screen of DNA methylation identifies novel markers in childhood obesity. Gene. 2015; 566(1):74-83.

2. Nevalainen T, Kananen L, Marttila S, Jylhava J, Mononen N, Kahonen M, Raitakari OT, Hervonen A, Jylha M, Lehtimaki T, et al. Obesity accelerates epigenetic aging in middle-aged but not in elderly individuals. Clin Epigenetics. 2017:9:20

3. Soubry A, Schildkraut JM, Murtha A, Wang F, Huang Z, Bernal A, Kurtzberg J, Jirtle RL, Murphy SK, Hoyo C. Paternal obesity is associated with IGF2 hypomethylation in newborns: results from a newborn epigenetics study (NEST) cohort. BMC Med. 2013;11:29.

4. van Dijk SJ, Molloy PL, Varinli H, Morrison JL, Muhlhausler BS, Members of Epi S. Epigenetics and human obesity. Int J Obes. 2015;39(1):85-97.

5. Xu X, Su S, Barnes VA, De Miguel C, Pollock J, Ownby D, Shi H, Zhu H, Snieder $\mathrm{H}$, Wang $\mathrm{X}$. A genome-wide methylation study on obesity: differential variability and differential methylation. Epigenetics. 2013;8(5): $522-33$

6. Sharp GC, Lawlor DA, Richmond RC, Fraser A, Simpkin A, Suderman M, Shihab HA, Lyttleton O, McArdle W, Ring SM, et al. Maternal pre-pregnancy $\mathrm{BMI}$ and gestational weight gain, offspring DNA methylation and later offspring adiposity: findings from the Avon longitudinal study of parents and children. Int J Epidemiol. 2015:44(4):1288-304.

7. Witt SH, Frank J, Gilles M, Lang M, Treutlein J, Streit F, Wolf IAC, Peus V, Scharnholz B, Send TS, et al. Impact on birth weight of maternal smoking throughout pregnancy mediated by DNA methylation. BMC Genomics. 2018:19(1):290

8. Lecoutre S, Petrus P, Ryden M, Breton C. Transgenerational epigenetic mechanisms in adipose tissue development. Trends Endocrinol Metab. 2018;29(10):675-85.

9. Ost A, Lempradl A, Casas E, Weigert M, Tiko T, Deniz M, Pantano L, Boenisch U, Itskov PM, Stoeckius M, et al. Paternal diet defines offspring chromatin state and intergenerational obesity. Cell. 2014;159(6):1352-64.

10. Dominguez-Salas P, Moore SE, Baker MS, Bergen AW, Cox SE, Dyer RA Fulford AJ, Guan Y, Laritsky E, Silver MJ, et al. Maternal nutrition at conception modulates DNA methylation of human metastable epialleles. Nat Commun. 2014;5:3746.

11. Tobi EW, Slieker RC, Luijk R, Dekkers KF, Stein AD, Xu KM, Biobank-based Integrative Omics Studies C, Slagboom PE, van Zwet EW, Lumey LH, et al. DNA methylation as a mediator of the association between prenatal adversity and risk factors for metabolic disease in adulthood. Sci Adv. 2018; 4(1):eaao4364

12. Bygren $L O$, Kaati $G$, Edvinsson S. Longevity determined by paternal ancestors' nutrition during their slow growth period. Acta Biotheor. 2001; 49(1):53-9.

13. Engel SM, Joubert BR, Wu MC, Olshan AF, Haberg SE, Ueland PM, Nystad W, Nilsen RM, Vollset SE, Peddada SD, et al. Neonatal genome-wide methylation patterns in relation to birth weight in the Norwegian mother and child cohort. Am J Epidemiol. 2014;179(7):834-42.

14. Kupers LK, Monnereau C, Sharp GC, Yousefi P, Salas LA, Ghantous A, Page CM, Reese SE, Wilcox AJ, Czamara D, et al. Meta-analysis of epigenome-wide association studies in neonates reveals widespread differential DNA methylation associated with birthweight. Nat Commun. 2019;10(1):1893.

15. Risnes KR, Vatten LJ, Baker JL, Jameson K, Sovio U, Kajantie E, Osler M, Morley R, Jokela M, Painter RC, et al. Birthweight and mortality in adulthood: a systematic review and meta-analysis. Int J Epidemiol. 2011;40(3):647-61.

16. Yu ZB, Han SP, Zhu GZ, Zhu C, Wang XJ, Cao XG, Guo XR. Birth weight and subsequent risk of obesity: a systematic review and meta-analysis. Obes Rev. 2011;12(7):525-42.

17. Dalgaard K, Landgraf K, Heyne S, Lempradl A, Longinotto J, Gossens K, Ruf M, Orthofer M, Strogantsev R, Selvaraj M, et al. Trim28 Haploinsufficiency triggers bi-stable epigenetic obesity. Cell. 2016;164(3):353-64.

18. Whitelaw NC, Chong S, Morgan DK, Nestor C, Bruxner TJ, Ashe A, Lambley E, Meehan R, Whitelaw E. Reduced levels of two modifiers of epigenetic gene silencing, Dnmt3a and Trim28, cause increased phenotypic noise. Genome Biol. 2010;11(11):R111.

19. Yang $\mathrm{CH}$, Andrew PJ. Polyphenism - a window into gene-environment interactions and phenotypic plasticity. Front Genet. 2019;10:132.
20. Eggermann T, Perez de Nanclares G, Maher ER, Temple IK, Tumer Z, Monk D, Mackay DJ, Gronskov K, Riccio A, Linglart A, et al. Imprinting disorders: a group of congenital disorders with overlapping patterns of molecular changes affecting imprinted loci. Clin Epigenetics. 2015;7:123.

21. Bigaard J, Frederiksen K, Tjonneland A, Thomsen BL, Overvad K, Heitmann BL, Sorensen TI. Body fat and fat-free mass and all-cause mortality. Obes Res. 2004;12(7):1042-9.

22. Henriksson P, Cadenas-Sanchez C, Leppanen MH, Delisle Nystrom C, Ortega FB, Pomeroy J, Ruiz JR, Lof M. Associations of Fat Mass and Fat-Free Mass with Physical Fitness in 4-Year-Old Children: Results from the MINISTOP Trial. Nutrients. 2016;8(8):473.

23. Wibaek R, Vistisen $D$, Girma T, Admassu B, Abera M, Abdissa A, Jorgensen ME, Kaestel P, Michaelsen KF, Friis H, et al. Associations of fat mass and fatfree mass accretion in infancy with body composition and cardiometabolic risk markers at 5 years: the Ethiopian iABC birth cohort study. PLoS Med. 2019;16(8):e1002888

24. De Cunto A, Paviotti G, Ronfani L, Travan L, Bua J, Cont G, Demarini S. Can body mass index accurately predict adiposity in newborns? Arch Dis Child Fetal Neonatal Ed. 2014:99(3):F238-9.

25. Eriksson B, Lof M, Forsum E. Body composition in full-term healthy infants measured with air displacement plethysmography at 1 and 12 weeks of age. Acta Paediatr. 2010;99(4):563-8.

26. Henriksson $P$, Lof $M$, Soderkvist $P$, Forsum E. Variation in the fat mass and obesity-related (FTO) genotype is not associated with body fatness in infants, but possibly with their length. Pediatric obesity. 2014;9(5):e112-5.

27. Ellis K, Yao M, Shypailo R, Urlando A, Wong W, Heird W. Body-composition assessment in infancy: air-displacement plethysmography compared with a reference 4-compartment model. Am J Clin Nutr. 2007:85(1):90-5.

28. Ma G, Yao M, Liu Y, Lin A, Zou H, Urlando A, Wong WW, NommsenRivers L, Dewey KG. Validation of a new pediatric air-displacement plethysmograph for assessing body composition in infants. Am J Clin Nutr. 2004;79(4):653-60.

29. Wahl S, Drong A, Lehne B, Loh M, Scott WR, Kunze S, Tsai PC, Ried JS, Zhang W, Yang Y, et al. Epigenome-wide association study of body mass index, and the adverse outcomes of adiposity. Nature. 2017;541(7635):81-6.

30. Henriksson P, Lof M, Forsum E. Glucose homeostasis variables in pregnancy versus maternal and infant body composition. Nutrients. 2015;7(7):5615-27.

31. Tyrrell J, Richmond RC, Palmer TM, Feenstra B, Rangarajan J, Metrustry S, Cavadino A, Paternoster L, Armstrong LL, De Silva NM, et al. Genetic evidence for causal relationships between maternal obesity-related traits and birth weight. JAMA. 2016;315(11):1129-40.

32. Collaborators GBDO, Afshin A, Forouzanfar MH, Reitsma MB, Sur P, Estep K Lee A, Marczak L, Mokdad AH, Moradi-Lakeh M, et al. Health effects of overweight and obesity in 195 countries over 25 years. N Engl J Med. 2017; 377(1):13-27.

33. Wells JC. A Hattori chart analysis of body mass index in infants and children Int J Obes Relat Metab Disord. 2000;24(3):325-9.

34. Goodarzi MO. Genetics of obesity: what genetic association studies have taught us about the biology of obesity and its complications. Lancet Diabetes Endocrinol. 2018;6(3):223-36.

35. Mook-Kanamori DO, Ay L, Hofman A, van Duijn CM, Moll HA, Raat $H$, Hokken-Koelega AC, Jaddoe WW. No association of obesity gene FTO with body composition at the age of 6 months. The generation R study. J Endocrinol Investig. 2011;34(1):16-20.

36. Bradfield JP, Taal HR, Timpson NJ, Scherag A, Lecoeur C, Warrington NM, Hypponen E, Holst C, Valcarcel B, Thiering E, et al. A genome-wide association meta-analysis identifies new childhood obesity loci. Nat Genet. 2012;44(5):526-31.

37. Felix JF, Bradfield JP, Monnereau C, van der Valk RJ, Stergiakouli E, Chesi A, Gaillard R, Feenstra B, Thiering E, Kreiner-Moller E, et al. Genome-wide association analysis identifies three new susceptibility loci for childhood body mass index. Hum Mol Genet. 2016;25(2):389-403.

38. Sovio U, Mook-Kanamori DO, Warrington NM, Lawrence R, Briollais L, Palmer CN, Cecil J, Sandling JK, Syvanen AC, Kaakinen M, et al. Association between common variation at the FTO locus and changes in body mass index from infancy to late childhood: the complex nature of genetic association through growth and development. PLoS Genet. 2011;7(2):e1001307.

39. Huang RC, Garratt ES, Pan H, Wu Y, Davis EA, Barton SJ, Burdge GC, Godfrey KM, Holbrook JD, Lillycrop KA. Genome-wide methylation analysis identifies differentially methylated $\mathrm{CpG}$ loci associated with severe obesity in childhood. Epigenetics. 2015;10(11):995-1005. 
40. Rzehak P, Covic M, Saffery R, Reischl E, Wahl S, Grote V, Weber M, Xhonneux A, Langhendries JP, Ferre N, et al. DNA-methylation and body composition in preschool children: Epigenome-wide-analysis in the European childhood obesity project (CHOP)-study. Sci Rep. 2017;7(1):14349.

41. Rounge TB, Page CM, Lepisto M, Ellonen P, Andreassen BK, Weiderpass E. Genome-wide DNA methylation in saliva and body size of adolescent girls. Epigenomics. 2016;8(11):1495-505.

42. Rushing A, Sommer EC, Zhao S, Po'e EK, Barkin SL. Salivary epigenetic biomarkers as predictors of emerging childhood obesity. BMC Med Genet 2020;21(1):34.

43. Fields DA, Goran Ml, McCrory MA. Body-composition assessment via airdisplacement plethysmography in adults and children: a review. Am J Clin Nutr. 2002;75:453-67.

44. Mansell G, Gorrie-Stone TJ, Bao Y, Kumari M, Schalkwyk LS, Mill J, Hannon E. Guidance for DNA methylation studies: statistical insights from the Illumina EPIC array. BMC Genomics. 2019;20(1):366.

45. Saftlas AF, Waldschmidt M, Logsden-Sackett N, Triche E, Field E. Optimizing buccal cell DNA yields in mothers and infants for human leukocyte antigen genotyping. Am J Epidemiol. 2004;160(1):77-84.

46. Islam SA, Goodman SJ, Maclsaac JL, Obradovic J, Barr RG, Boyce WT, Kobor MS. Integration of DNA methylation patterns and genetic variation in human pediatric tissues help inform EWAS design and interpretation. Epigenetics Chromatin. 2019;12(1):1.

47. Lowe R, Gemma C, Beyan H, Hawa MI, Bazeos A, Leslie RD, Montpetit A Rakyan VK, Ramagopalan SV. Buccals are likely to be a more informative surrogate tissue than blood for epigenome-wide association studies. Epigenetics. 2013;8(4):445-54.

48. Lowe R, Slodkowicz G, Goldman N, Rakyan VK. The human blood DNA methylome displays a highly distinctive profile compared with other somatic tissues. Epigenetics. 2015;10(4):274-81.

49. Forest M, O'Donnell KJ, Voisin G, Gaudreau H, Maclsaac JL, McEwen LM, Silveira PP, Steiner M, Kobor MS, Meaney MJ, et al. Agreement in DNA methylation levels from the Illumina 450K array across batches, tissues, and time. Epigenetics. 2018;13(1):19-32.

50. Henriksson P, Lof M, Forsum E. Parental fat-free mass is related to the fatfree mass of infants and maternal fat mass is related to the fat mass of infant girls. Acta Paediatr. 2015;104(5):491-7.

51. Matthews DR, Hosker JP, Rudenski AS, Naylor BA, Treacher DF, Turner RC. Homeostasis model assessment: insulin resistance and beta-cell function from fasting plasma glucose and insulin concentrations in man. Diabetologia. 1985;28(7):412-9.

52. Fortin JP, Labbe A, Lemire M, Zanke BW, Hudson TJ, Fertig EJ, Greenwood CM, Hansen KD. Functional normalization of 450k methylation array data improves replication in large cancer studies. Genome Biol. 2014;15(12):503.

53. Aryee MJ, Jaffe AE, Corrada-Bravo H, Ladd-Acosta C, Feinberg AP, Hansen KD, Irizarry RA. Minfi: a flexible and comprehensive bioconductor package for the analysis of Infinium DNA methylation microarrays. Bioinformatics. 2014;30(10):1363-9.

54. Zhou W, Laird PW, Shen H. Comprehensive characterization, annotation and innovative use of Infinium DNA methylation BeadChip probes. Nucleic Acids Res. 2017;45(4):e22

55. Edgar RD, Jones MJ, Robinson WP, Kobor MS. An empirically driven data reduction method on the human $450 \mathrm{~K}$ methylation array to remove tissue specific non-variable CpGs. Clin Epigenetics. 2017;9:11.

\section{Publisher's Note}

Springer Nature remains neutral with regard to jurisdictional claims in published maps and institutional affiliations.

Ready to submit your research? Choose BMC and benefit from:
- fast, convenient online submission
- thorough peer review by experienced researchers in your field
- rapid publication on acceptance
- support for research data, including large and complex data types
- gold Open Access which fosters wider collaboration and increased citations
- maximum visibility for your research: over 100M website views per year
At BMC, research is always in progress.
Learn more biomedcentral.com/submissions

